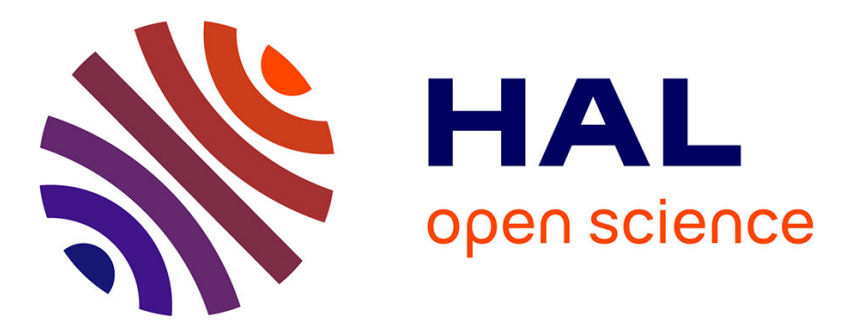

\title{
Amino-substituted-1,1-dicyano-2,4-diaryl-1,3-butadiene chromophores: Synthesis and photophysical properties
}

Mohamed Yahya, Nurgül Seferoğlu, Alberto Barsella, Sylvain Achelle, Zeynel Seferoğlu

\section{- To cite this version:}

Mohamed Yahya, Nurgül Seferoğlu, Alberto Barsella, Sylvain Achelle, Zeynel Seferoğlu. Aminosubstituted-1,1-dicyano-2,4-diaryl-1,3-butadiene chromophores: Synthesis and photophysical properties. Spectrochimica Acta Part A: Molecular and Biomolecular Spectroscopy [1994-..], 2021, 248, pp.119178. 10.1016/j.saa.2020.119178 . hal-03038038

\section{HAL Id: hal-03038038 \\ https://hal.science/hal-03038038}

Submitted on 15 Dec 2020

HAL is a multi-disciplinary open access archive for the deposit and dissemination of scientific research documents, whether they are published or not. The documents may come from teaching and research institutions in France or abroad, or from public or private research centers.
L'archive ouverte pluridisciplinaire HAL, est destinée au dépôt et à la diffusion de documents scientifiques de niveau recherche, publiés ou non, émanant des établissements d'enseignement et de recherche français ou étrangers, des laboratoires publics ou privés. 


\section{Amino-substituted-1,1-dicyano-2,4-diaryl-1,3-butadiene}

\section{chromophores: Synthesis and photophysical properties}

Mohamed Yahya ${ }^{\mathrm{a}}$, Nurgül Seferoğlu ${ }^{\mathrm{b}}$, Alberto Barsellac ${ }^{\mathrm{c}}$, Sylvain Achelle ${ }^{\mathrm{d}}$, Zeynel Seferoğlu*a

a Department of Chemistry, Faculty of Science, Gazi University, Yenimahalle, Ankara 06560,

Turkey

${ }^{b}$ Department of Advanced Technology, Gazi University, Yenimahalle, Ankara 06560, Turkey

'Département d'Optique ultrarapide et Nanophotonique, IPCMS, UMR CNRS 7504,

Université de Strasbourg, 23 rue du Loess, BP 43, 67034 Strasbourg Cedex 2, France

dUniv Rennes, CNRS, Institut des Sciences Chimiques de Rennes - URM 6226, 35000 Rennes,

France

*E-mail address: znseferoglu@gazi.edu.tr (Z. Seferoğlu)

\section{GRAPHICAL ABSTRACT}

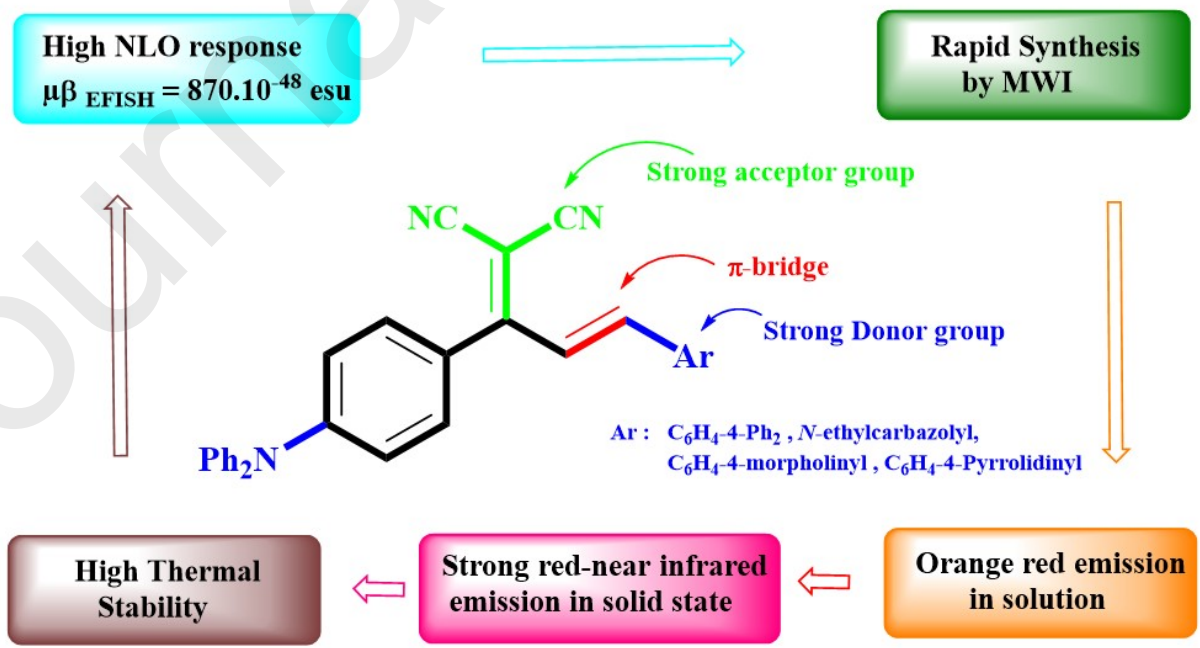


Abstract

A series of $\mathrm{D}-\pi$-A chromophores based on allylidenemalononitrile electron-withdrawing group was designed. The influence of the amino-electron-donating group on the photophysical properties was studied. These compounds, highly thermally stable, exhibit orange-red emission in solution and in solid state. The experimental results have been rationalized by theoretical DFT calculations. The second order nonlinear optical properties were also studied using the electric field induced second harmonic generation (EFISH) method.

Keywords: allylidenemalononitrile; NIR emission; push-pull; triphenylamine; Intramolecular charge transfer (ICT), DFT calculations.

\section{Introduction}

During the last three decades there has been a great interest for the development of organic structures presenting intramolecular charge transfer (ICT). These compounds are based on an electron-donating group D linked to an electron accepting part A via a $\pi$-conjugated bridge (D- $\pi$-A structure, also called push-pull compounds). Push-pull structures have been extensively used for their optoelectronic properties [1].

Many push-pull derivatives exhibit fluorescence properties in solution. The emission properties can be easily tuned by modification of one of the three parts of the D- $\pi$-A structure [2]. An increase of the ICT will lead to red-shift of absorption and emission spectra [3]. However aggregation caused quenching (ACQ) often occurs mainly due to non-radiative processes and face to face $\pi-\pi$ intermolecular interactions in solid state [4]. Triphenylamine 
and nitrile-rich push-pull chromophores are however known to be good solid-state fluorophores [5,6], with applications ranging from OLEDs [7], solid state lasers [8], and luminescent sensors [9].

The D- $\pi$-A structure is also typical of second order nonlinear optical (NLO) chromophores [10]. Second order NLOphores were extensively used for second harmonic generation, this permits for example to obtain blue/green laser from red sources [11]. Optical signal process and optical data storage application can be based on second order NLO phenomenon [12]. For push-pull derivatives, the NLO response is closely related to ICT.

Compounds with 1,1-dicyano-2,4-diaryl-1,3-butadiene scaffold are known for their bright strong color useful for textile dying [13]. When substituted by electron-donating groups these compounds exhibit interesting NLO properties [14]. Recently, such structures have been used for recognition of serum albumin in urine and imaging in living cells [15]. Sekar and coworkers have recently demonstrated that in case of substitution by two amino groups in para position of both phenyls in 1,1-dicyano-2,4-diphenyl-1,3-butadiene, the ICT occurs from the amino group of phenyl in C4 position to both cyano groups [16].

In this contribution we will describe the photophysical properties, including solid state emission, of a series of 1,1-dicyano-2,4-diaryl-1,3-butadiene derivatives 3a-d that are substituted by various amino groups on both side (Scheme 1). Rationalization of experimental results will be performed with the help of (TD-)DFT calculations. 


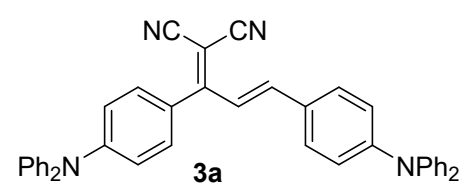<smiles>CCc1ccc(/C=C/C(=C(C#N)C#N)c2ccc(Nc3ccccc3)cc2)cc1</smiles><smiles>N#CC(C#N)=C(/C=C/c1ccc(N2CCOCC2)cc1)c1ccc(Nc2ccccc2)cc1</smiles><smiles>N#CC(C#N)=C(/C=C/c1ccc(N2CCCC2)cc1)c1ccc(Nc2ccccc2)cc1</smiles>

Chart 1.

\section{Experimental}

\subsection{Materials and instrumentation}

The chemicals used in the synthesis of all compounds were obtained from Aldrich Chemical Company (USA) and were used without further purification. Compound $\mathbf{1}$ was obtained according to reported procedure [17]. All solvents used were of analytical grade. Solvents were dried according to standard procedures. All reactions were magnetically stirred and monitored by thin-layer chromatography (TLC) using Merck silica gel $\left(60 \mathrm{~F}_{254}\right)$ plates $(0.25 \mathrm{~mm})$ and visualized with Ultraviolet light. FT-IR (ATR) spectra were recorded on Thermo Scientific Nicolet iS5 FTIR Spectrometer (Gazi University Department of Chemistry, Turkey) in KBr ( $v$, in $\left.\mathrm{cm}^{-1}\right) .{ }^{1} \mathrm{H}$ NMR and ${ }^{13} \mathrm{C}$ spectra were recorded on a Bruker Ultrashield $\left({ }^{1} \mathrm{H}: 400 \mathrm{MHz},{ }^{13} \mathrm{C} 100\right.$ MHz) spectrometer (Hacettepe University, Department of Chemistry, Turkey) in DMSO- $d_{6}$. Chemical shifts are expressed in $\delta$ units (ppm) with tetramethylsilane (TMS) as the internal reference. Coupling constants $(J)$ are given in hertz $(\mathrm{Hz})$. Signals are abbreviated as follows: singlet, s; doublet, d; doublet-doublet, dd; triplet, t; multiplet, m. All melting points are uncorrected and in degrees Celsius $\left({ }^{\circ} \mathrm{C}\right)$ (Electrothermal 9200 melting point apparatus). High- 
resolution mass spectra (HRMS) were recorded at Gazi University, Faculty of Pharmacy, Turkey using electron ionization (EI) mass spectrometry Waters-LCT-Premier-XE-LTOF (TOF-MS) instruments in $\mathrm{m} / \mathrm{z}$ (rel. \%). Absorption and photoluminescence spectra were recorded on a Spex Fluoromax-3 Jobin-Yvon Horiba spectrophotometer (at IUT Lannion, University of Rennes 1, France). Compounds were excited at their absorption maxima (band of lowest energy) to record the emission spectra. Fluorescence quatum yield $( \pm 10 \%)$ were determined relative to $9-10$ bis(phenylethynyl)anthracene in cyclohexane $\left(\Phi_{F}=1.00\right)$ according to known procedure [18]. Experimental details on EFISH measurements are described elsewhere [19].

\subsection{Computational details}

The ground state geometries of compounds 3a-d were carried out at B3LYP/6311g(d) level by using Density Functional Theory (DFT) [20]. The absorption spectra were calculated by using time-dependent DFT (TD-DFT) method. The first excited state geometries of the compounds were also calculated within TD-DFT methods. In all calculations, $\mathrm{CHCl}_{3}$ was used polarizable continuum model (PCM) [21]. The calculations were performed using the Gaussian 09 package program [22].

\subsection{Synthesis and characterization}

2-(1-(4-(diphenylamino)phenyl)ethylidene)malononitrile (2) [16]. A mixture of 1 (1 mmol) and malononitrile $(1 \mathrm{mmol})$ in a $\mathrm{NH}_{4} \mathrm{AcO} / \mathrm{AcOH}$ buffer $10 \mathrm{ml}$ were irradiated in a microwave at $120^{\circ} \mathrm{C}, 300 \mathrm{~W}$ for $4 \mathrm{~min}$. Then the crude was cooled in an ice bath. The residue was washed several times with ethanol in order to get rid of acetic acid. The crude compound was purified by recrystallization form ethanol to provide compound $\mathbf{2}$ as orange crystal, Yield: (1.1 g, 
94\%). m.p: $163-165^{\circ} \mathrm{C}$. FTIR (KBr, v cm$\left.{ }^{-1}\right): 3047,2216,1585,1557,1489,1318 .{ }^{1} \mathbf{H}$ NMR (400 MHz, DMSO-d $\left.)_{6}\right) \delta .66(\mathrm{~d}, J=8.7 \mathrm{~Hz}, 2 \mathrm{H}), 7.44-7.40(\mathrm{~m}, 4 \mathrm{H}), 7.25-7.18(\mathrm{~m}, 6 \mathrm{H}), 6.86$ (d, $J=8.7 \mathrm{~Hz}, 2 \mathrm{H}), 2.57(\mathrm{~s}, 3 \mathrm{H}) .{ }^{13} \mathbf{C}$ NMR (100 MHz, DMSO- $\left.d_{6}\right): 174.9,151.8,145.9$, $130.5,127.0,126.8,125.9,118.4,115.0,114.7,79.0,23.9$.

General procedure for the preparation of dyes 3a-d: A mixture consisting of $2(0.6 \mathrm{mmol})$ and different aldehydes $(0.6 \mathrm{mmol})$ was dissolved in ethanol $(10 \mathrm{ml})$, piperidine $(0.1 \mathrm{~mL})$ was then added, and this reaction mass was allowed to stir at room temperature for 12 hours under nitrogen. On completion of the reaction(TLC control), the mass was poured over water to give a crude product. The crude mass was filtered, washed with a small volume of ethanol, and dried. This crude product was further purified by column chromatography using silica gel (120-200 mesh) with toluene as eluent.

(E)-2-(1,3-bis(4-(diphenylamino)phenyl)allylidene)malononitrile (3a) [16] : Dark Red solid, Yield: (418 mg, 71\%). m.p: 176-178 ${ }^{\circ} \mathrm{C}$. FTIR (KBr, v cm-1): 3033, 2210, 1573, 1480, 1330. ${ }^{1} \mathrm{H}$ NMR (400 MHz, DMSO- $\left.d_{6}\right) \delta 7.59(\mathrm{~d}, J=7.9 \mathrm{~Hz}, 2 \mathrm{H}), 7.45-7.35(\mathrm{~m}, 10 \mathrm{H}), 7.31(\mathrm{~d}, J=$ $16.0 \mathrm{~Hz}, 1 \mathrm{H}), 7.25-7.15(\mathrm{~m}, 8 \mathrm{H}), 7.15-7.10(\mathrm{~m}, 4 \mathrm{H}), 7.01(\mathrm{~d}, J=16.0 \mathrm{~Hz}, 1 \mathrm{H}), 6.93(\mathrm{~d}, J=$ $7.6 \mathrm{~Hz}, 2 \mathrm{H}), 6.86(\mathrm{~d}, J=7.4 \mathrm{~Hz}, 2 \mathrm{H}) . \mathrm{HRMS}(\mathrm{m} / \mathrm{z}),(\mathrm{M}+\mathrm{H})^{+}: \mathrm{C}_{42} \mathrm{H}_{31} \mathrm{~N}_{4}$, calculated: 591.2543 ; found: 591.2547

(E)-2-(4-(diphenylamino)phenyl)-(9-ethyl-9H-carbazol-3-yl)allylidene)malononitrile (3b):

Red orange solid, Yield: $(313 \mathrm{mg}, 69 \%) . \mathrm{m} \cdot \mathrm{p}=180-182^{\circ} \mathrm{C}$. FTIR $\left(\mathrm{KBr}, v \mathrm{~cm}^{-1}\right): 3041,2969$, 2216, 1580, 1484. ${ }^{1} \mathrm{H}$ NMR (400 MHz, DMSO- $\left.d_{6}\right) \delta 8.58(\mathrm{~s}, 1 \mathrm{H}), 8.24(\mathrm{~d}, J=7.7 \mathrm{~Hz}, 1 \mathrm{H})$, $7.89(\mathrm{~d}, J=8.6 \mathrm{~Hz}, 1 \mathrm{H}), 7.72-7.66(\mathrm{~m}, 2 \mathrm{H}), 7.56(\mathrm{~d}, J=15.2 \mathrm{~Hz}, 1 \mathrm{H}), 7.54-7.49(\mathrm{~m}, 1 \mathrm{H})$ $7.45-7.42(\mathrm{~m}, 6 \mathrm{H}), 7.31(\mathrm{~d}, J=15.2 \mathrm{~Hz}, 1 \mathrm{H}), 7.33-7.15(\mathrm{~m}, 6 \mathrm{H}), 7.15-7.11(\mathrm{~m} 1 \mathrm{H}), 6.98$ 
$(\mathrm{d}, J=8.1 \mathrm{~Hz}, 2 \mathrm{H}), 4.48(\mathrm{q}, J=6.9 \mathrm{~Hz}, 2 \mathrm{H}), 1.32(\mathrm{t}, J=6.8 \mathrm{~Hz}, 3 \mathrm{H}) .{ }^{13} \mathrm{C}$ NMR $(100 \mathrm{MHz}$, DMSO- $\left.d_{6}\right) \delta 171.6,151.2,150.8,146.4,142.1,140.6,131.7,130.5,127.1,127.0(2 \mathrm{C}), 126.5$, $126.0,125.5,125.3,123.9,123.4,122.7,121.6,121.4,120.4,119.3,115.7,114.9,110.6$, 110.3, 76.1, 37.9, 14.2. HRMS (m/z), $(\mathrm{M}+\mathrm{H})^{+}: \mathrm{C}_{38} \mathrm{H}_{29} \mathrm{~N}_{4}$, calculated: 541.2387; found: 541.2375 .

(E)-2-(4-(diphenylamino)phenyl)-3-(4-morpholinophenyl)allylidene)malononitrile

(3c): brown solid, Yield: $(300 \mathrm{mg}, 59 \%) . \mathrm{m} . \mathrm{p}=165-167{ }^{\circ} \mathrm{C}$. FTIR $\left(\mathrm{KBr}, v \mathrm{~cm}^{-1}\right): 3031,2841$, 2215, 1577, 1472. ${ }^{1} \mathbf{H}$ NMR $\left(300 \mathrm{MHz}, \mathrm{CDCl}_{3}\right) \mathrm{d} 7.48(\mathrm{~d}, \mathrm{~J}=8.8 \mathrm{~Hz}, 2 \mathrm{H}), 7.41-7.31(\mathrm{~m}, 6 \mathrm{H})$, 7.26-7.12 (m, 7H), $7.06(\mathrm{~d}, J=8.6 \mathrm{~Hz}, 2 \mathrm{H}), 6.97(\mathrm{~d}, J=15.4 \mathrm{~Hz}, 1 \mathrm{H}), 6.86(\mathrm{~d}, J=8.8 \mathrm{~Hz}$, 2H), $3.86(\mathrm{t}, \mathrm{J}=4.5 \mathrm{~Hz}, 4 \mathrm{H}), 3.31(\mathrm{t}, \mathrm{J}=4.5 \mathrm{~Hz}, 4 \mathrm{H}) .,{ }^{13} \mathbf{C}$ NMR $\left(100 \mathrm{MHz}, \mathrm{DMSO}-d_{6}\right) \delta$ $170.7,153.2,150.1,149.2,145.8,131.1,131.0,129.9,125.9,124.9,124.8,124.0119 .5$, 118.9, 115.3, 114.5, 113.8, 74.7, 65.8, 46.6. HRMS (m/z), $(\mathrm{M}+\mathrm{H})^{+}: \mathrm{C}_{34} \mathrm{H}_{29} \mathrm{~N}_{4} \mathrm{O}$, calculated: 509.2336; found: 509.2324 .

(E)-2-(4-(diphenylamino)phenyl)-3-(4-(pyrrolidin)phenyl)allylidene)malononitrile (3d): Bronze solid, Yield: (450 mg, 92\%). m.p $=150-152{ }^{\circ} \mathrm{C}$. FTIR $\left(\mathrm{KBr}, v \mathrm{~cm}^{-1}\right): 3000,2868$, 2204, 1569, 1474. ${ }^{1} \mathbf{H}$ NMR $\left(400 \mathrm{MHz}, \mathrm{DMSO}-d_{6}\right) \delta 7.55(\mathrm{~d}, J=8.8 \mathrm{~Hz}, 2 \mathrm{H}), 7.41(\mathrm{t}, J=7.8$ $\mathrm{Hz}, 4 \mathrm{H}), 7.34(\mathrm{~d}, J=8.6 \mathrm{~Hz}, 2 \mathrm{H}), 7.24-7.16(\mathrm{~m}, 7 \mathrm{H}), 6.99$ (d, $J=15.9, \mathrm{~Hz}, 1 \mathrm{H}), 6.96(\mathrm{~d}, J$ $=8.8 \mathrm{~Hz}, 2 \mathrm{H}), 6.61(\mathrm{~d}, J=8.8 \mathrm{~Hz}, 2 \mathrm{H}), 3.31(\mathrm{~s}, 4 \mathrm{H}), 1.97(\mathrm{~s}, 4 \mathrm{H}) . \mathbf{H R M S}(\mathrm{m} / \mathrm{z}),(\mathrm{M}+\mathrm{H})^{+}$: $\mathrm{C}_{34} \mathrm{H}_{29} \mathrm{~N}_{4}$, calculated: 493.2387; found: 493.2369 . 


\section{Results and discussion}

\subsection{Synthesis}

The synthesis of compounds 3a-d is presented in Scheme 1. At the first step 1-(4(diphenylamino)phenyl)ethan-1-one (1) was converted to 2-(1-(4-(diphenylamino)phenyl) ethylidene)malononitrile (2) in the presence of $\mathrm{NH}_{4} \mathrm{OAc} / \mathrm{AcOH}$ using microwave irradiation (MWI) by improved synthetic methods with higher yield [16]. Final products (3a-d) were synthesized by the piperidine-catalyzed condensation reaction of $\mathbf{2}$ and corresponding aldehydes in boiling ethanol. The structures of the synthesized dyes were confirmed by FTIR, NMR, and mass spectroscopic techniques. The ${ }^{1} \mathrm{H}$ NMR spectra demonstrated that all compounds have a vinylic coupling constant $\left(J_{H H}=15-16 \mathrm{~Hz}\right)$ of the olefinic protons, confirming that only the formation of $E$ stereoisomer could be detected.

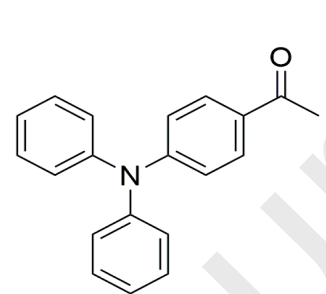

1

Q:<smiles>CC(C)(C)c1ccc(N(P)c2ccccc2)cc1</smiles>

3a, $71 \%$

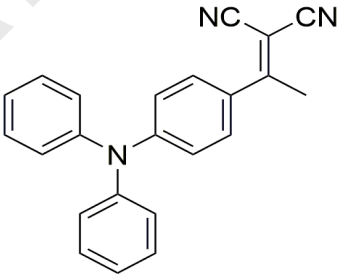

2, $94 \%$

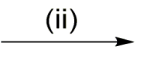<smiles>[Y]c1ccc(N2CCOCC2)cc1</smiles>

$3 c, 59 \%$<smiles>N#CC(C#N)=C(/C=C/O)c1ccc(N(c2ccccc2)c2ccccc2)cc1</smiles>

3a-d

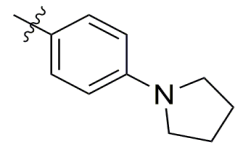

3d, $92 \%$

Scheme 1. Synthesis of 1,1-dicyano-2,4-diaryl-1,3-butadiene derivatives (3a-d). (i) malononitrile, $\mathrm{NH}_{4} \mathrm{OAc} / \mathrm{AcOH}, \mathrm{MWI}$ (ii) Q-CHO, ethanol, piperidine. 


\subsection{Linear optical properties}

The UV/Vis and photoluminescence (PL) spectroscopic data of compounds 3a-d measured in $\mathrm{CHCl}_{3}$ at room temperature are presented in Table 1 . The normalized UV/Vis and PL spectra are shown in Figure 1. All compounds exhibit two absorption bands: one located around 300 $\mathrm{nm}$ and a second one, attributed to charge transfer $\pi-\pi^{*}$ transition, in the $450-510 \mathrm{~nm}$ range. Diphenylamino and pyrrolidinyl derivatives 3a and 3d exhibit significantly red-shifted absorption with regard to carbazole and morpholine substituted compounds $\mathbf{3 b}$ and $\mathbf{3 c}$. A significant hyperchromism can be observed for the charge transfer absorption band of $\mathbf{3 d}$ with molar extinction coefficient that is 2-1.5 times higher than those of chromophores 3a-c. In chloroform solution, compounds 3a-d exhibit orange-red emission with moderate quantum yield $\left(\Phi_{\mathrm{F}}\right)$ (below 0.10$)$. The emission maximum of compound $\mathbf{3 d}$ is significantly blue-shifted with regards to compounds 3a-c. The pyrrolidinyl derivatives 3d exhibit therefore a significantly lower stokes shift which may be explained by a lower steric hindrance with the pyrrolidine fragment, decreasing the torsional twist of the amino group in ground state. The diphenylamino derivative 3a $\left(\Phi_{F}=0.10\right)$ exhibits the highest quantum yield. According to the literature data for the analogue of compound 3a without $\mathrm{NPh}_{2}$ substituent on phenyl ring in the $\mathrm{C} 2$ position [23]. it appears that this diphenylamino group induces a blue shift in absorption $(9 \mathrm{~nm})$ but a red-shift $(25 \mathrm{~nm})$ in emission. 
Table 1. UV-Vis absorption and photoluminescence (PL) data of compounds 3a-d in $\mathrm{CHCl}_{3}$ solution

\begin{tabular}{ccccccc}
\hline Compound & $\lambda_{\text {abs }}(\mathbf{n m})$ & $\begin{array}{c}\boldsymbol{\varepsilon}\left(\mathbf{m M}^{-1}\right. \\
\left.\mathbf{c m}^{-1}\right)\end{array}$ & $\begin{array}{c}\lambda_{\text {em }} \\
(\mathbf{n m})\end{array}$ & $\Phi_{\mathbf{F}}$ & $\begin{array}{c}\text { Stokes Shift } \\
\left(\mathbf{c m}^{-1}\right)\end{array}$ & $\begin{array}{c}\text { Brightness } \\
\left(\mathbf{m M}^{-1} \mathbf{c m}^{-1}\right)\end{array}$ \\
\hline 3a & 304,493 & $40.5,49.0$ & 644 & 0.10 & 4760 & 4.9 \\
\hline 3b & 297,456 & $31.7,36.1$ & 654 & 0.046 & 6640 & 1.7 \\
\hline 3c & 299,461 & $24.4,36.2$ & 659 & 0.044 & 6520 & 1.6 \\
\hline 3d & 303,507 & $40.4,72.2$ & 594 & 0.023 & 2890 & 1.7
\end{tabular}

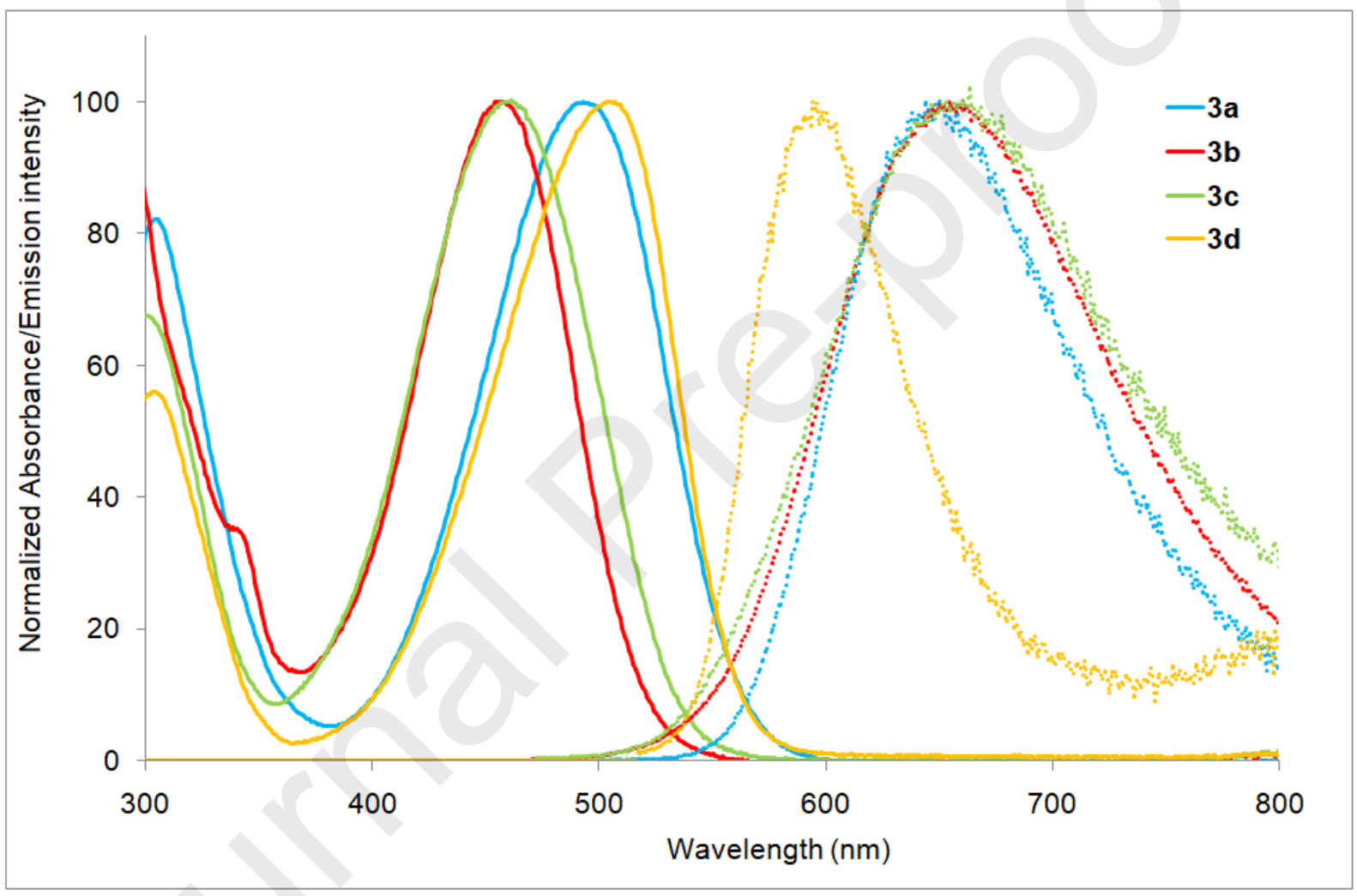

Fig. 1. Normalized absorption (solid lines) and emission (dashed lines) spectra of compounds 3a-d in chloroform solution.

It is well known that fluorophores presenting ICT exhibit intense positive solvatochromism whereas their absorption spectra are less affected by the solvent [24]. Indeed highly polar excited states of push-pull chromophores are stabilized by polar solvents. The emission spectra of compounds 3a-d were therefore registered is a series of aprotic solvents of 
increasing polarity. The results are presented in Table 2. As an example the normalized spectra of compound 3a are shown in Figure 2. For all compounds, as expected a large positive emission solvatochromism is observed. It should be noted that in the case of compounds 3a-c the emission is fully quenched in solvent of higher polarity than DCM. Emission in acetone and $\mathrm{MeCN}$ can be however detected in the case of compound $\mathbf{3 d}$. For all compounds, this is in chlorinated solvents $\left(\mathrm{CHCl}_{3}\right.$ or DCM) that the emission intensity is the highest (Figures S19-21). For all compounds, the emission maxima were plotted versus the Reichardt polarity parameter [25]. (Figure S22), and in all cases, a good linearity is observed. Once again the peculiar behavior of pyrrolidinyl derivative $\mathbf{3 d}$ can be observed with a significantly lower value of the slope of the corresponding regression line. This may indicate a lower contribution from twisted intramolecular charge transfer (TICT) than for 3a-c.

Table 2. Emission solvatochromism of compounds 3a-d in various aprotic solvents.

\begin{tabular}{|c|c|c|c|c|c|c|c|c|c|}
\hline $\begin{array}{c}\text { Compound } \\
\mathbf{E}_{\mathrm{T}} \mathbf{3 0} \\
(\mathrm{kcal} / \mathrm{mol})\end{array}$ & $\begin{array}{c}n- \\
\text { heptane } \\
30.9\end{array}$ & $\begin{array}{c}\text { Toluene } \\
33.9 \\
\end{array}$ & $\begin{array}{c}1,4- \\
\text { dioxane } \\
36.0\end{array}$ & $\begin{array}{l}\text { THF } \\
37.4 \\
\end{array}$ & $\begin{array}{c}\mathrm{CHCl}_{3} \\
39.1\end{array}$ & $\begin{array}{c}\text { DCM } \\
40.7 \\
\end{array}$ & $\begin{array}{c}\text { Acetone } \\
42.2 \\
\end{array}$ & $\begin{array}{c}\text { MeCN } \\
45.6 \\
\end{array}$ & $\begin{array}{c}\text { Solid } \\
\text { State } \\
\text { (powder) }\end{array}$ \\
\hline $3 a$ & 555 & 589 & 606 & 650 & 644 & 673 & $-^{a}$ & $-a$ & 657 \\
\hline $3 b$ & 550 & 587 & 620 & 667 & 654 & 694 & $-a$ & $-a$ & 663 \\
\hline $3 c$ & 538 & 580 & 602 & 607 & 659 & 697 & $-{ }^{a}$ & $-{ }^{a}$ & 688 \\
\hline 3d & 539 & 567 & 577 & 605 & 594 & 607 & 623 & 628 & 706 \\
\hline
\end{tabular}

${ }^{a}$ no emission detected 


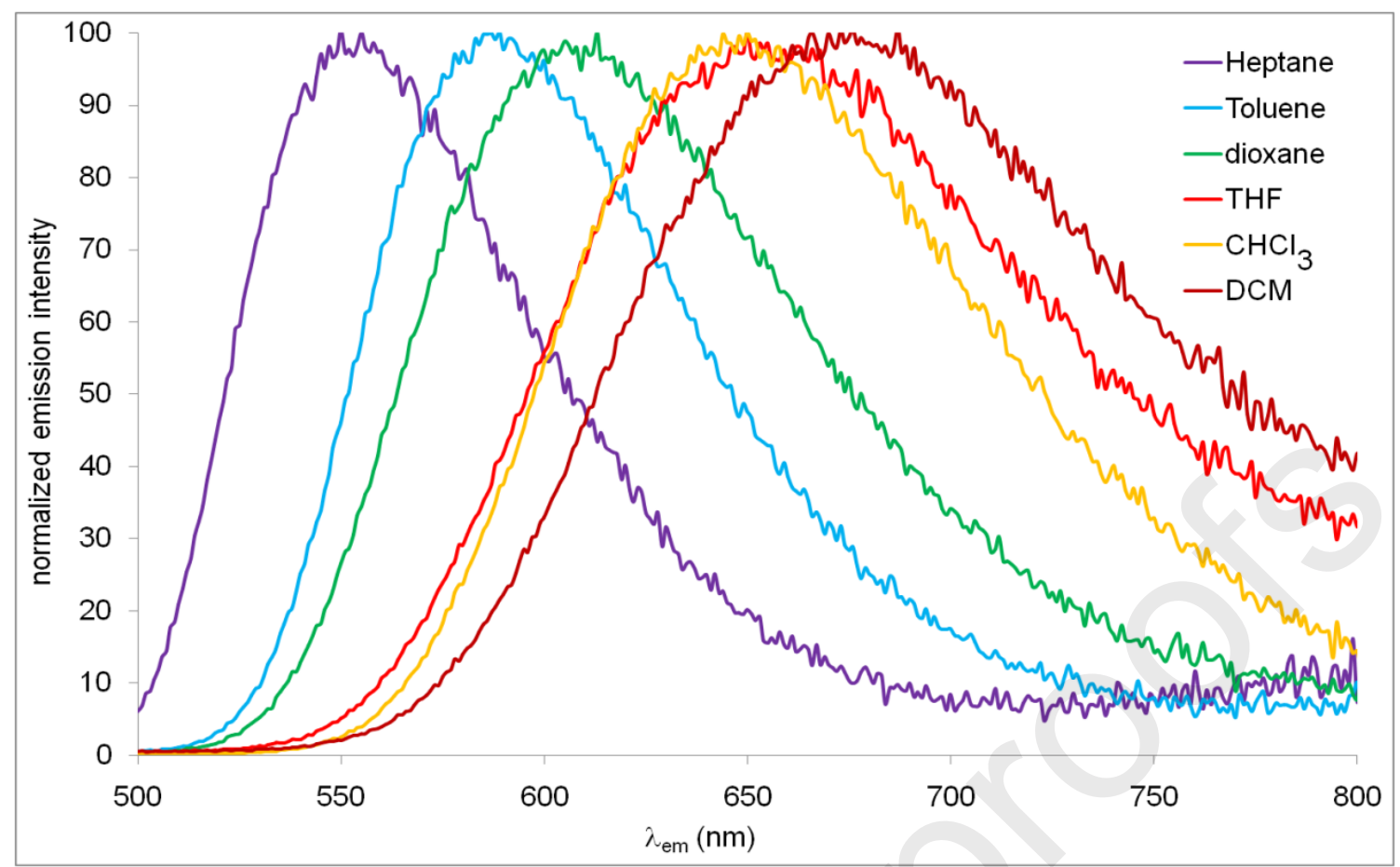

Fig. 2. Normalized emission spectra of 3a in different aprotic solvents

All compounds also exhibit strong red-near infrared emission in solid state (powder) (Figures 3 and 4). Compound 3d is the most red-shifted with $\lambda_{\mathrm{em}}=706 \mathrm{~nm}$. The emission spectra of compounds $\mathbf{3 b}$ and $\mathbf{3 c}$ are significantly broader with full half width maximum (FHWM) around $3500 \mathrm{~cm}^{-1}$ in both cases. 


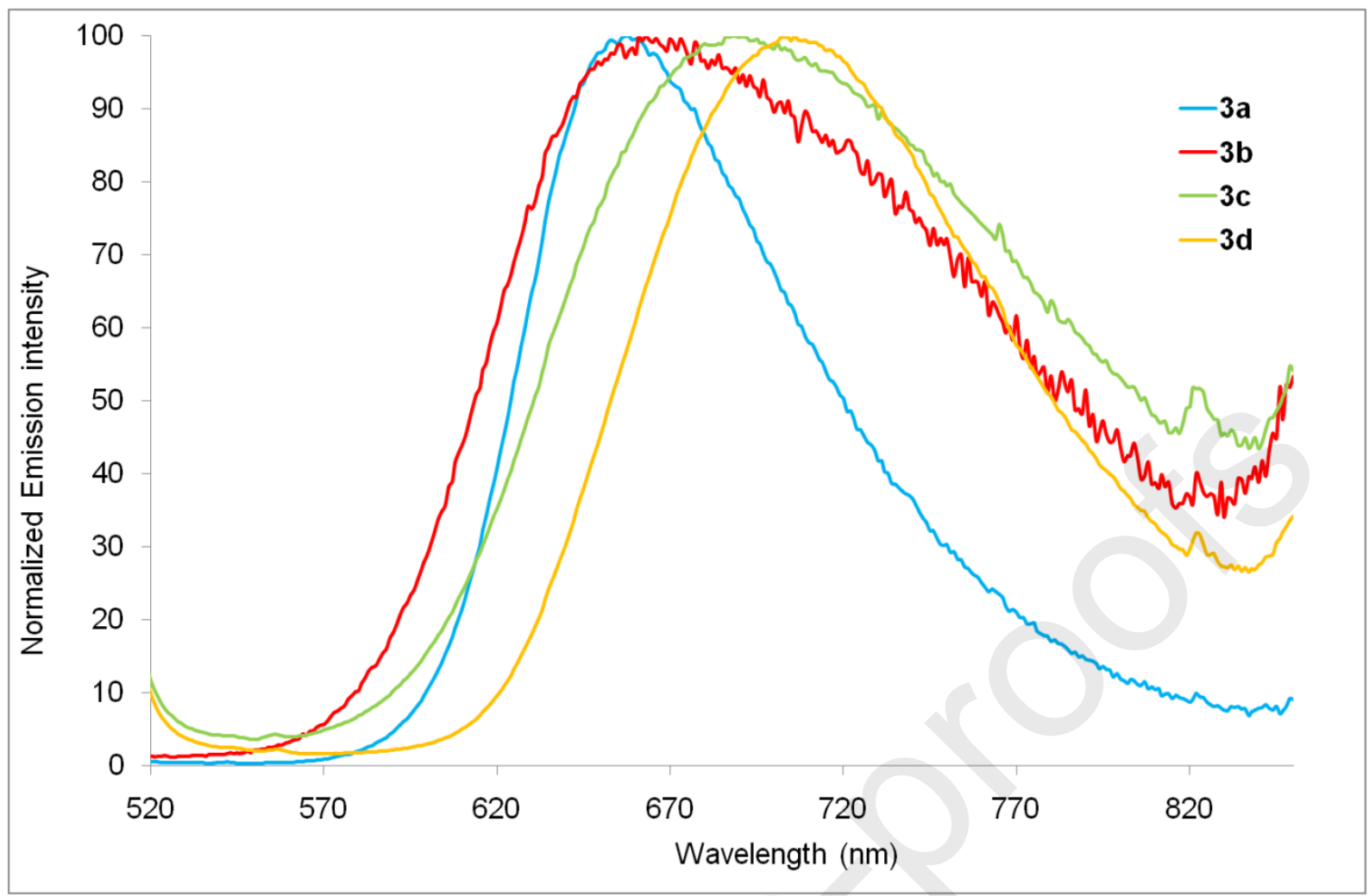

Fig. 3. Normalized solid state (powder) spectra of compounds 3a-d.
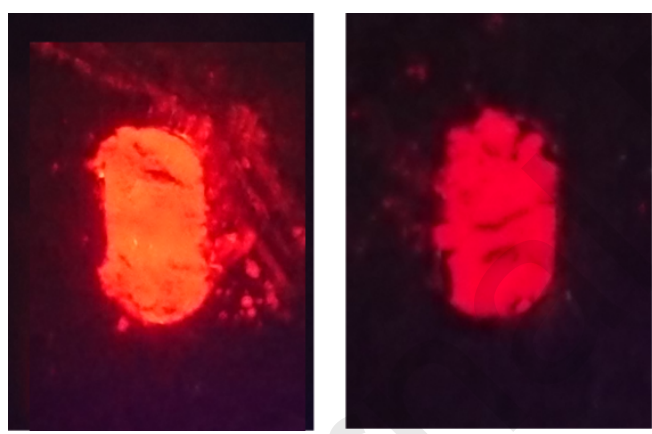

Fig. 4. Emission of compound 3a and 3c in solid state (powder). Photograph was taken in the dark upon irradiation with a hand-held UV lamp $\left(\lambda_{\mathrm{em}}=366 \mathrm{~nm}\right)$

\subsection{Theoretical calculation}

In order to rationalize experimental results, (TD)-DFT calculation has been performed. The optimized ground and excited state geometries of compounds 3a-d are presented in Figure 5. In ground state geometries, a small twist angle between the dicyanomethylene and the aryl 
groups in $\mathrm{C} 4$ position of the 1,1-dicyano-1,3-butadiene fragment was observed as $16.41^{\circ}$ for compound $\mathbf{3 a}, 17.18^{\circ}$ for compound $\mathbf{3 b}, 14.89^{\circ}$ for compound $\mathbf{3}, 15.65^{\circ}$ for compound $\mathbf{3 d}$. In excited state, the dicyanomethylene and the aryl groups in $\mathrm{C} 4$ position became more planar with a smaller twist angle in the range of $0.19-1.1^{\circ}$ and the phenyl ring of triphenylamine became nearly perpendicular to the plane the dicyanomethylene with the dihedral around $88^{\circ}$ for all compounds. For compound 3d the dihedral angle between the pyrrolidine fragment and the adjacent phenyl ring is of $3.96^{\circ}$ and $6.07^{\circ}$ in ground and excited states, respectively. On the other hand for compound 3c, the morpholine moiety is twisted of $12.38^{\circ}$, and $45.46^{\circ}$ in ground and excited state. This is in accordance with the lower Stokes shift and less extended emission solvatochromism observed experimentally for compound 3d 
ground state
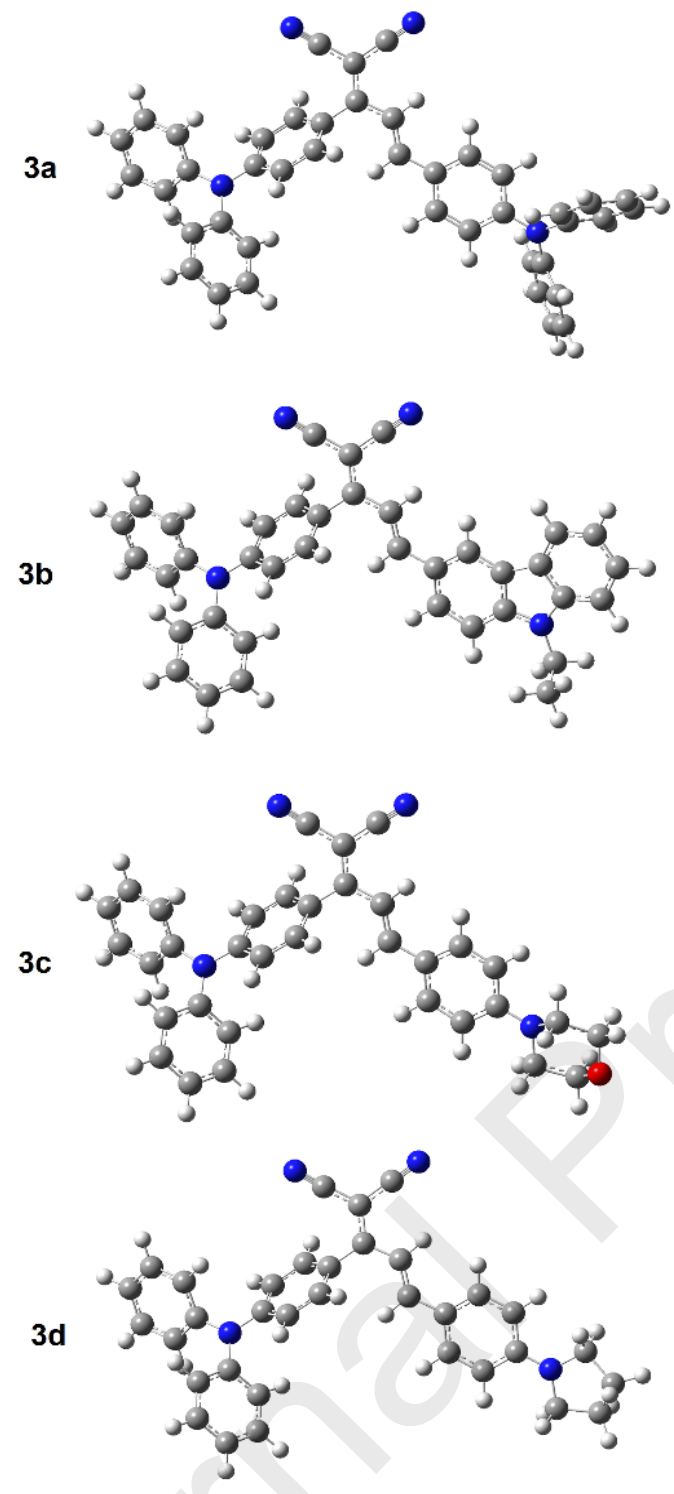

excited state
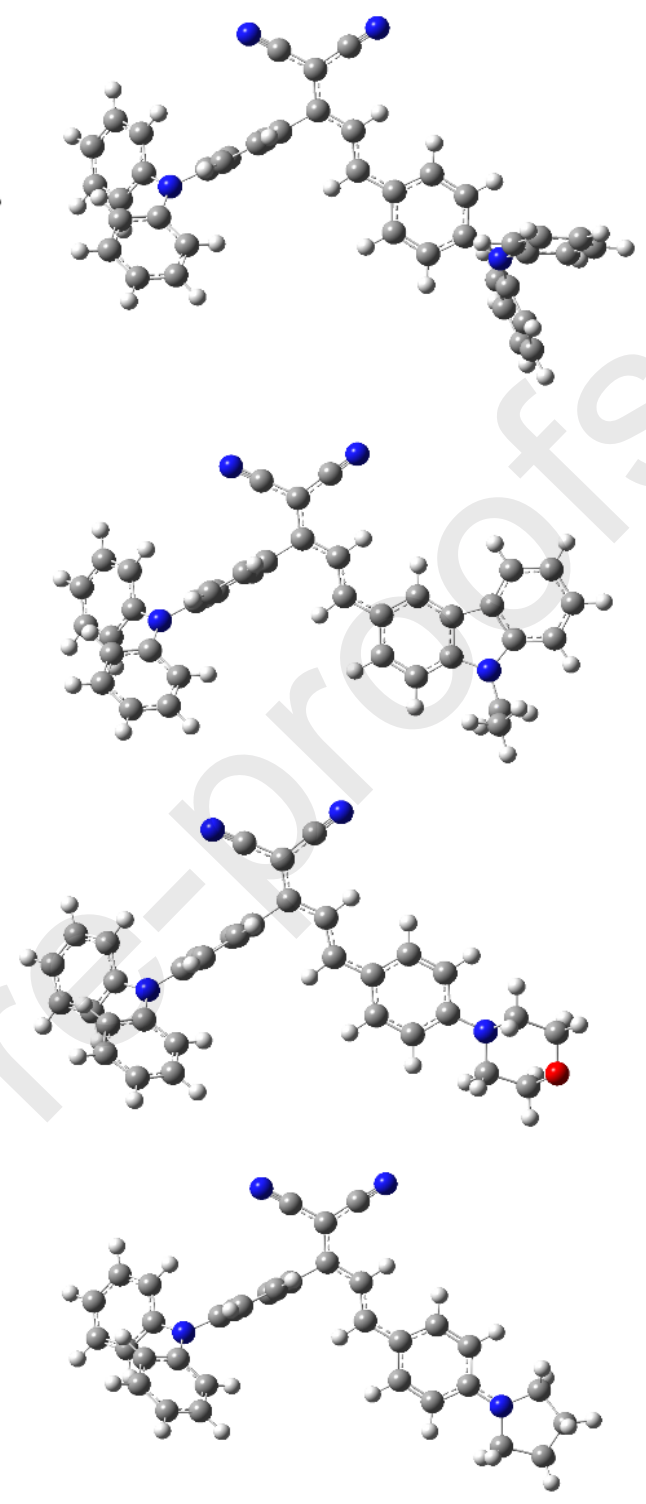

Fig. 5. The optimized geometries of compounds 3a-d in ground and excited state at B3LYP/6311g(d) in $\mathrm{CHCl}_{3}$.

The absorption and emission maxima obtained from TD-DFT calculations in $\mathrm{CHCl}_{3}$ on the ground and first excited states, respectively, are given in Table 3. The absorption maxima of compounds $\mathbf{3 a}$ and $\mathbf{3 d}$ appear to be higher than compounds $\mathbf{3 b}$ and $\mathbf{3} \mathbf{c}$ in accordance with experimental results. TD-DFT calculations on the first excited state reproduce well the emission band observed for compound 3a. However, for compounds $\mathbf{3 b - d}$ the calculated 
emission maxima are significantly blue-shifted with regards to experimental data. The molecular orbitals (HOMO-1 and LUMO) related to the main peak in absorption and emission spectra were illustrated in Figure 6. It can be clearly observed that the electron densities shift from the amino groups in $\mathrm{C} 4$ position of the 1,1-dicyano-1,3-butadiene fragment to the dicyanomethylene through vinyl bridge, and there is no contribution from the triphenylamine in $\mathrm{C} 2$ position.

Table 3. The absorption and emission spectra data obtained from TD-DFT calculations in $\mathrm{CHCl}_{3}$ for compounds 3a-d.

\begin{tabular}{|c|c|c|c|c|c|c|c|c|}
\hline & \multicolumn{4}{|c|}{ Absorbance } & \multicolumn{4}{|c|}{ Emission } \\
\hline & $\lambda_{\max }^{\text {abs }}$ & f & Transitions & $\begin{array}{c}\text { Contribution } \\
(\%)\end{array}$ & $\lambda_{\max }^{e m}$ & f & Transitions & $\begin{array}{c}\text { Contribution } \\
(\%)\end{array}$ \\
\hline \multirow[t]{2}{*}{$3 \mathbf{a}$} & 524 & 0.8014 & $\begin{array}{l}\mathrm{HOMO}-1 \rightarrow \mathrm{LUMO} \\
\mathrm{HOMO} \rightarrow \mathrm{LUMO}\end{array}$ & $\begin{array}{c}92.2 \\
7.2\end{array}$ & 637 & 0.9004 & HOMO-1 $\rightarrow$ LUMO & 99.4 \\
\hline & 353 & 0.3899 & $\begin{array}{l}\mathrm{HOMO}-2 \rightarrow \mathrm{HOMO} \\
\mathrm{HOMO}-1 \rightarrow \mathrm{LUMO}+1\end{array}$ & $\begin{array}{c}90.7 \\
5.1\end{array}$ & & & & \\
\hline \multirow[b]{2}{*}{ 3b } & 473 & 0.758 & HOMO- $1 \rightarrow$ LUMO & 96.5 & 516 & 1.021 & HOMO-1 $\rightarrow$ LUMO & 97.3 \\
\hline & 338 & 0.2722 & $\begin{array}{l}\mathrm{HOMO}-3 \rightarrow \mathrm{LUMO} \\
\mathrm{HOMO} \rightarrow \mathrm{HOMO}+1 \\
\mathrm{HOMO} \rightarrow \mathrm{LUMO}+2 \\
\mathrm{HOMO} \rightarrow \mathrm{LUMO}+3\end{array}$ & $\begin{array}{c}20.9 \\
52.9 \\
20.5 \\
2.2\end{array}$ & & & & \\
\hline \multirow[b]{2}{*}{ 3c } & 464 & 1.0793 & HOMO-1 $\rightarrow$ LUMO & 98.4 & 495 & 1.4144 & HOMO-1 $\rightarrow$ LUMO & 99.6 \\
\hline & 332 & 0.3908 & $\begin{array}{l}\mathrm{HOMO}-3 \rightarrow \text { LUMO } \\
\mathrm{HOMO}-2 \rightarrow \text { LUMO } \\
\mathrm{HOMO} \rightarrow \text { LUMO+1 } \\
\mathrm{HOMO} \rightarrow \text { LUMO+2 }\end{array}$ & $\begin{array}{c}4.3 \\
22.9 \\
53.3 \\
10.9\end{array}$ & & & & \\
\hline \multirow[b]{2}{*}{ 3d } & 482 & 1.0694 & $\begin{array}{l}\text { HOMO- } 1 \rightarrow \text { LUMO } \\
\text { HOMO } \rightarrow \text { LUMO }\end{array}$ & $\begin{array}{c}94.1 \\
5.7\end{array}$ & 512 & 1.5699 & HOMO-1 $\rightarrow$ LUMO & 99.9 \\
\hline & 332 & 0.4113 & $\begin{array}{l}\mathrm{HOMO}-2 \rightarrow \text { LUMO } \\
\mathrm{HOMO}-1 \rightarrow \text { LUMO+1 } \\
\mathrm{HOMO}-1 \rightarrow \text { LUMO+2 } \\
\mathrm{HOMO} \rightarrow \text { LUMO+1 } \\
\mathrm{HOMO} \rightarrow \text { LUMO+2 }\end{array}$ & $\begin{array}{c}15.4 \\
9.6 \\
3.1 \\
52.5 \\
13.1\end{array}$ & & & & \\
\hline
\end{tabular}




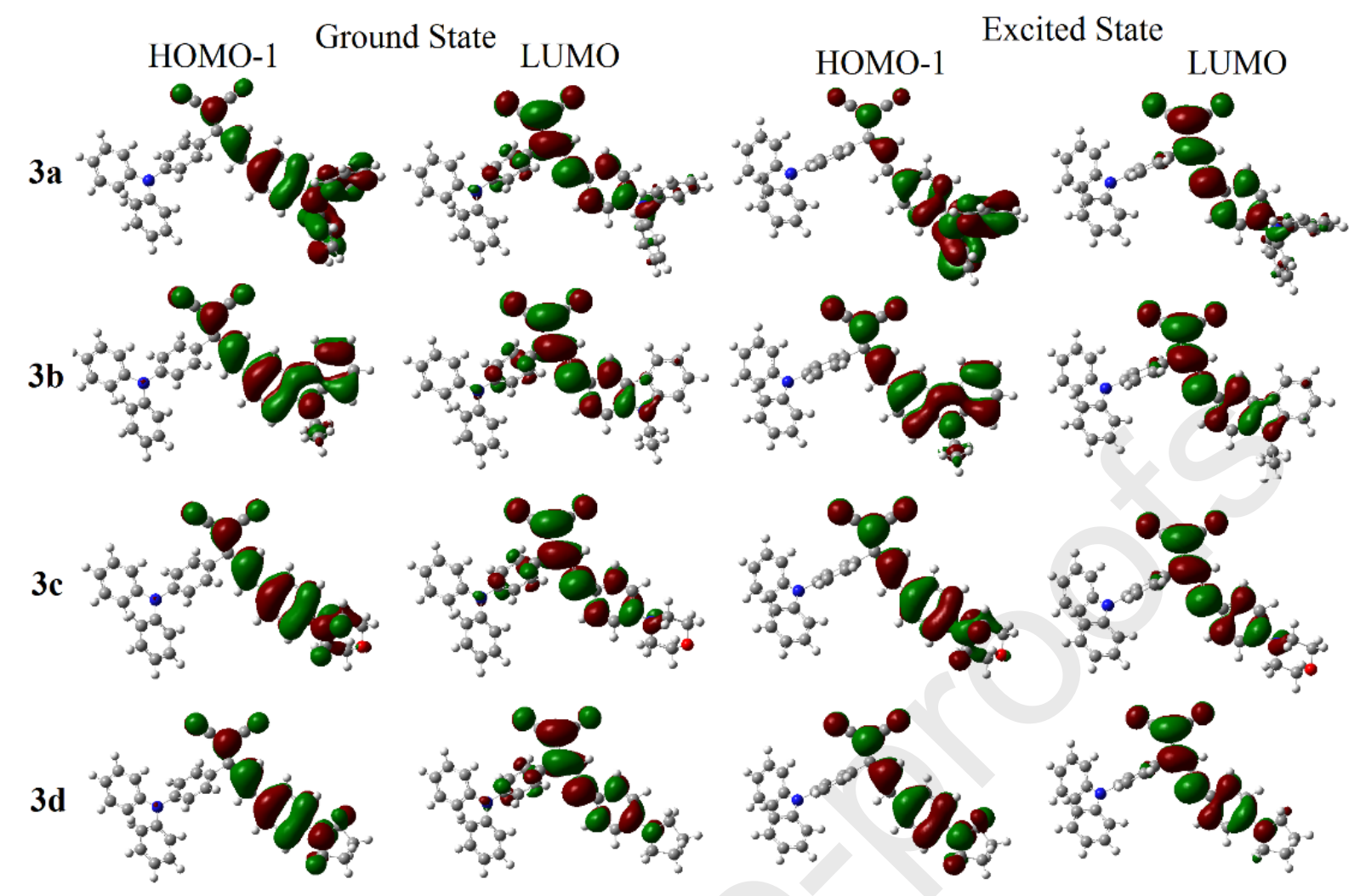

Fig. 6. The molecular orbitals of compounds 3a-d in ground and excited state.

\subsection{Second order NLO properties}

The second order NLO properties have been studied in chloroform solution by the electricfield induced second harmonic generation (EFISH) method at a non-resonant incident wavelength of $1907 \mathrm{~nm}$. The second harmonic at $\lambda=953 \mathrm{~nm}$ is therefore well clear of the absorption bands of the chromophores. This method provides the NLO response as the scalar product between the permanent dipole moment of the molecule $\vec{\mu}$ in fundamental state and the vector component of $\beta$ described as $\beta_{/ /}$[26]. The two levels corrected $\mu \beta$ values $\left(\mu \beta_{0}\right)$ have been also calculated [27]. The results are presented in Table 4. It should be noted that positive $\mu \beta$ values are obtained indicating that both ground and excited states are polarized in the same direction and that the excited state is more polarized than ground state, in accordance with the observed positive emission solvatochromism. Relatively high $\mu \beta_{0}$ values, higher to diperse 
Red 1 (DR1), generally unsed as reference, are observed in all cases. In accordance with the red-shifted absorption maxima observed for 3d, indicating a stronger ICT, this compound exhibits the highest NLO response. The results show that the compounds have comparable NLO response while comparing with counterparts [14].

Table 4. Results for EFISH measurements for compounds 3a-d.

\begin{tabular}{cccccc}
\hline & 3a & 3b & 3c & 3d & DR1 $^{[28]}$ \\
\hline$\mu \beta\left(10^{-48}\right.$ & 950 & 900 & 800 & 1300 & 740 \\
esu $)^{a}$ & & & & & \\
$\mu \beta_{0}\left(10^{-48}\right.$ & 650 & 650 & 580 & 870 & 490 \\
esu $)^{b}$ & & & & & \\
\hline
\end{tabular}

${ }^{a} \mu \beta(2 \omega)$ at $1907 \mathrm{~nm}$ in $\mathrm{CHCl}_{3}$. Molecular concentrations used for the measurements were in the range of $10^{-3}$ to $10^{-2} \mathrm{M}, \mu \beta \pm 10 \%{ }^{b}$ Two level corrected $\mu \beta$ values $\left(\mu \beta_{0}\right)$ [26].

\subsection{Thermal stability}

In order to study the thermal stability of these chromophores, thermogravimetric analyses (TGA) were performed. As depicted from Fig 7, all compounds do not exhibit any significant weight loss weight up to $300{ }^{\circ} \mathrm{C}$. More precisely, the onset decomposition temperature (Td) of compounds 3a-d are $347{ }^{\circ} \mathrm{C}(96 \%), 340{ }^{\circ} \mathrm{C}(97 \%), 352{ }^{\circ} \mathrm{C}(95 \%)$ and $339{ }^{\circ} \mathrm{C}(94 \%)$, respectively. These series of chromophores exhibit high thermal stability, which is compatible with the applied material fabrication process. 


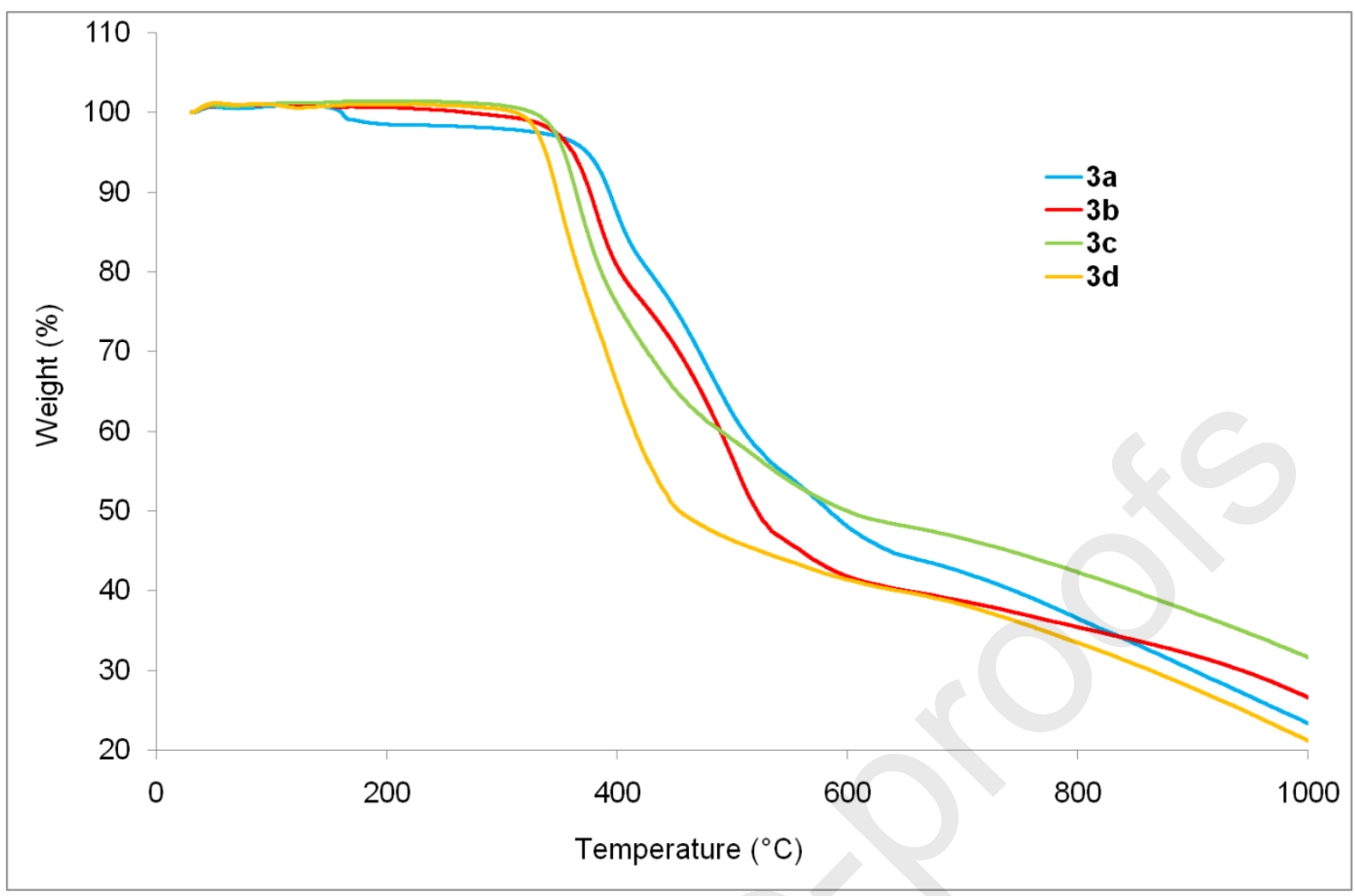

Fig. 7. TGA curves of chromophores 3a-d under nitrogen gas in the temperature range of 25$600{ }^{\circ} \mathrm{C}$ at a heating rate of $10{ }^{\circ} \mathrm{C} \mathrm{min}^{-1}$.

\section{Conclusion}

In summary, a series of four 1,1-dicyano-2,4-diaryl-1,3-butadiene bearing various amino electron-donating moieties in $\mathrm{C} 4$ position was designed. These compounds, highly thermally stable, exhibit orange-red emission in chloroform solution in solid state. These compounds exhibit intense positive emission solvatochromism in aprotic solvents, which is characteristic of ICT. The pyrrolidine derivative, that displays the most red-shifted absorption band, exhibits the strongest ICT which is attributed a more planar structure either in ground and excited state, due to reduced steric hindrance. This compound exhibits the highest NLO response of this series. This series of chromophores that can be easily synthesized in gram scale and 
exhibit interesting NLO response have potential interest in the conception of materials for optical data processing.

\section{References}

[1] a) S. Forrest, M. Thompon , special issue on " organic electronics and optoelectronics », Chem. Rev., 107 (2007) 923-925 . https://doi.org/10.1021/cr0501590. b) R. D. Miller, E.A. Chandross, special issue on «materials for electronics", Chem. Rev. 110 (2010) 1-2. https://doi.org/10.1021/cr900384b. c) M. Mayor, Special issue on "Molecular electronicsfrom a visionary concept towards reality”, Chimia, 64 (2010) 348-349 ; d) J. L. Bredes, J.R. Durrant, Special issue on « Organic photovoltaics », Acc. Chem. Res. 42 (2009) 1689-1690. https://doi.org/10.1021/ar900238j.

[2] F. Bureš, Fundamental aspects of property tuning in push-pull molecules, RSC Adv. 4 (2014) 58826-58851. https://doi.org/10.1039/C4RA11264D.

[3] M. Remond, Z. Zheng, E. Jeanneau, C. Andraud, Y. Bretonniere, S. Redon, 4,5,5Trimethyl-2,5-dihydrofuran-Based Electron-Withdrawing Groups for NIR-Emitting Push-Pull Dipolar Fluorophores, J. Org. Chem. $84 \quad$ (2019) 9965-9974. https://doi.org/10.1021/acs.joc.9b01120.

[4] a) J. Mei, N.L. Leung, R.T. Kwok, J.W. Lam, B.Z. Tang, Aggregation-Induced Emission: Together We Shine, United We Soar!, Chem. Rev., 115 (2015) 11718-11940. https://doi.org/10.1021/acs.chemrev.5b00263. b) S. Gupta, M.D. Milto, Design and synthesis of novel V-shaped AIEE active quinoxalines for acidochromic applications, Dyes Pigm., 165 (2019) 474-487. https://doi.org/10.1016/j.dyepig.2019.02.038.

[5] a) B. Zhang, H. Wu, Z. Wang, A. Qin, B.Z. Tang, Planarized intramolecular charge transfer on triphenylamine-modified pyrazine and its application in organic light-emitting diodes, J. Mater. Chem. C, 8 (2020) 4754-4762. https://doi.org/10.1039/D0TC00626B. b) Y. 
Zhang, K. Wang, G. Zhuang, Z. Xie, C. Zhang, F. Cao, G. Pan, H. Chen, B. Zou, Y. Ma, Multicolored-Fluorescence Switching of ICT-Type Organic Solids with Clear Color Difference: Mechanically Controlled Excited State, Chem. Eur. J. 21 (2015) 2474-2479. https://doi.org/10.1002/chem.201405348. c) X. Han, Q. Bai, L. Yao, H. Liu, Y. Gao, J. Li, L. Liu, Y. Liu, X. Li, P. Lu, B. Yang, Highly Efficient Solid-State Near-Infrared Emitting Material Based on Triphenylamine and Diphenylfumaronitrile with an EQE of $2.58 \%$ in Nondoped Organic Light-Emitting Diode, Adv. Funct. Mater. 25 (2015) 7521-7529. https://doi.org/10.1002/adfm.201503344.

[6] a) S.V. Fedoseev, M.Y Belikov, M.Y Levlev, O.V. Ershov, V.A. Tafeenko, Tuning solidstate fluorescence of a novel group D- $\pi$-A chromophores with a reactive hydroxytricyanopyrrole (HTCP) acceptor, Dyes Pigm., 165 (2019) 451-457. https://doi.org/10.1016/j.dyepig.2019.02.036. b) M. Ipuy, Y.Y. Liao, E. Jeanneau, P. Baldeck, Y. Bretonnière, C. Andraud, Solid state red biphotonic excited emission from small dipolar fluorophores, J. Mater. Chem. C, $4 \quad$ (2016) 766-779. https://doi.org/10.1039/C5TC03465E.

[7] a) W. Qin, J.W. Lam, Z. Yang, S. Chen, G. Liang, W. Zhao, H.S. Kwok, B.Z. Tang, Red emissive AIE luminogens with high hole-transporting properties for efficient non-doped OLEDs, Chem. Commun. 51 (2015) 7321-7324. https://doi.org/10.1039/C5CC01690H. b) C.T. Chen, Evolution of Red Organic Light-Emitting Diodes: Materials and Devices, Chem. Mater. 16 (2004) 4389-4400. https://doi.org/10.1021/cm049679m

[8] I.D.W. Samuel, G.A. Turnbull, Organic Semiconductor Lasers, Chem. Rev. 107 (2007) 1272-1295. https://doi.org/10.1021/cr050152i.

[9] a) A. Kalika, A.H. Malik, N.S. Sarma, Stimuli-Responsive Naphthalene Diimide as Invisible Ink: A Rewritable Fluorescent Platform for Anti-Counterfeiting, Chem. Asian J. 15 (2020) 1074-1080. https://doi.org/10.1002/asia.201901800. b) M. Echeverri, M. ; C. Ruiz, C. ; 
S. Gámez-Valenzuela, S. ; M. Alonso-Navarro, M. ; E. Gutierrez-Puebla, J.L. Serrano, M.C. Ruiz Delgado, B. Gomez-Lor, Stimuli-Responsive Benzothiadiazole Derivative as a Dopant for Rewritable Polymer Blends, ACS Appl. Mater. Interfaces 12 (2020) 10929-10937. https://doi.org/10.1021/acsami.9b21209. c) J. P. Malval, M. Cranney, S. Achelle, H. AkdasKilic, J. L. Fillaut, N. Cabon , F. Robin-le Guen, O. Soppera, Y. Molard, Porosity-driven large amplitude dynamics for nitroaromatic sensing with fluorescent films of alternating D- $\pi-$ A molecules, Chem. Commun. $55 \quad$ (2019) 14331-14334. https://doi.org/10.1039/C9CC07227F.

[10] a) S. Barlow, S.R Marder, Nonlinear Optical Properties of Organic Materials. In: Functional Organic Materials; Müller, T. J. J.; Bunz, U. H. F. Eds.; Wiley-VCH: Weinheim, Germany, (2007) 393-437. https://doi.org/10.1002/adfm.200301006. b) M. Szablewski, P. R. Thomas, A. Thornton, D. Bloor, Highly Dipolar, Optically Nonlinear Adducts of Tetracyanop-quinodimethane: Synthesis, Physical Characterization, and Theoretical Aspects, J. Am. Chem. Soc. 119 (1997) 3144-3154. https://doi.org/10.1021/ja963923w. c) R. R. Tykwinski, U. Gubler, R. E. Martin, F. Diederich, C. Bosshard, P. Günter, Structure-Property Relationships in Third-Order Nonlinear Optical Chromophores, J. Phys. Chem. B 102 (1998) 4451-4465. https://doi.org/10.1021/jp980829o.

[11] a) H. Kerdoncuff, J. B. Christensen, T. B. Brasil, V. A. Novikov, E. S. Polzik, J. Hald, M. Lassen, Coherent frequency bridge between visible and telecommunications band for vortex light, Optics Express, 20 (2020) 3975-3984. https://doi.org/10.1364/OE.25.024290. b) A. L. Moura, A. L.; S. J. M. Carreno, S. J. M.; P. I. R. Pincheira, Z. V. Fabris, L. J. Q. Maia, A. S. L. Gomes, C. B. de Araujo, Tunable ultraviolet and blue light generation from Nd:YAB random laser bolstered by second-order nonlinear processes, Sci. Rep. 6 (2016) 27107. https://doi.org/10.1038/srep27107 
[12] a) R. Dorn, D. Baumns, P. Kersten, R. Regener, Nonlinear optical materials for integrated optics: Telecommunications and sensors, Adv. Mater. 4 (1992) 464 - 473. https://doi.org/10.1002/adma.19920040703. b) S. R. Marder, J. W. Perry, Molecular materials for second-order nonlinear optical applications, Adv. Mater. 5 (1993) 804-815. https://doi.org/10.1002/adma.19930051104. c) D. Dini, M. J. F. Calvete, M. Hanack, Nonlinear Optical Materials for the Smart Filtering of Optical Radiation, Chem. Rev. 116 (2016) 13043-13233. https://doi.org/10.1021/acs.chemrev.6b00033. (d) J. Liu, C. Ouyang, F. Huo, W. He, A. Cao, Progress in the enhancement of electro-optic coefficients and orientation stability for organic second-order nonlinear optical materials, Dyes Pigm. 181 (2020) 108509. https://doi.org/10.1016/j.dyepig.2020.108509.

[13] U.V. Gokhale, S. Seshadri, Synthesis of 1,1-dicyano-2,4-diaryl-1,3-butadienes-a novel chromophore, Dyes Pigm. 7 (1986) 389-394. https://doi.org/10.1016/0143-7208(86)80006-7. [14] a) E. Çatal, E. Keleş, N. Seferoğlu, S. Achelle, A. Barsella, F. Robin-le Guen, Z. Seferoğlu, Triphenylamine-based allylidenemalononitrile chromophores: synthesis, and photophysical and second-order nonlinear optical properties, New J. Chem. 42 (2018) 1505215060. https://doi.org/10.1039/C8NJ02794C. b) U. Warde , N. Sekar, Fluorescent Benzocoumarin- $\pi$-Extended Styryl Hybrids: Solvatochromism, Excess Dipole Moment, NLO Properties and DFT Study, J. Fluoresc. 28 (2018) 293-309. https://doi.org/10.1007/s10895017-2192-1. c) N. Seferoğlu, Y. Bayrak, E. Yalçin, Z. Seferoğlu, Synthesis and investigation of various properties of a novel series of nonlinear optical (NLO) chromophores bearing dicyanovinyl (DCV) moiety, J. Mol. Struct. $1149 \quad$ (2017) 510-519. https://doi.org/10.1016/j.molstruc.2017.07.102. d) E. Yalçin, S. Achelle, Y. Bayrak, N. Seferoğlu, A. Barsella, Z. Seferoğlu, Styryl-based NLO chromophores: synthesis, spectroscopic properties, and theoretical calculations, Tetrahedron Lett. 56 (2015) 25862589. https://doi.org/10.1016/j.tetlet.2015.03.133. e) M. M. Raikwar, K.C. Avhad, M. Varghese, 
E. Mathew, I. H. Joe, N. Sekar, D- $\pi-A-\pi-D$ coumarin hybrids derived from arylamine donors: DFT and Z-scan studies, Opt Mater. 92 (2019) 100-110. https://doi.org/10.1016/j.optmat.2019.04.011

[15] T. Zhu, J. Du, W. Cao, J. Fan, X. Peng, Microenvironment-Sensitive Fluorescent Dyes for Recognition of Serum Albumin in Urine and Imaging in Living Cells, Ind. Eng. Chem. Res. 55 (2016) 527-533. https://doi.org/10.1021/acs.iecr.5b04214.

[16] M. M. Raikwar, E. Mathew, M. Varghese, I. H. Joe, N. N. Sekar, NLO phoric Triphenylamine Derived Donor- $\pi$-Acceptor- $\pi$-Donor Based Colorants: Synthesis, Spectroscopic, Density Functional Theory and Z-scan Studies, Photochem. Photobiol. 95 (2019) 931-945. https://doi.org/10.1111/php.13089.

[17] H.L. Wang, B. Zhang, W.Y. Xu, Y.Q. Bai, H. Wu, (4-Acetylphenyl)diphenylamine, Acta $\begin{array}{llllllll}\text { Crystallogr. Sect. E } & \text { (2007) 2648-2649. }\end{array}$ https://doi.org/10.1107/S1600536807017904.

[18] D. F. Eaton, Reference materials for fluorescence measurements Pure Appl. Chem. 1988, 60, 1107-1114. https://doi.org/10.1351/pac198860071107

[19] G. Ulrich, A. Barsella, A. Boeglin, S. Niu, R. Ziessel, BODIPY-bridged push-pull chromophores for nonlinear applications. ChemPhysChem, 2014, 15, 2693-2700.

[20] (a) W. Kohn, L. J. Sham, Self-Consistent Equations Including Exchange And $\begin{array}{llllll}\text { Correlation } & \text { Effects } & \text { Phys. } & \text { Rev., } & 1965, & 140,\end{array}$ https://doi.org/10.1103/PhysRev.140.A1133; (b) A. D. Becke, Density-Functional Thermochemistry. III. The Role Of Exact Exchange. J. Chem. Phys., 1993, 98, 5648-5652 https://doi.org/10.1063/1.464913.

[21] (a) J. Tomasi, R. Cammi, B. Mennucci, C. Cappelli, S. Corni, Molecular Properties In Solution Described With A Continium Solvation Model Phys. Chem. Chem. Phys., 2002, 24, 5697-5712 https://doi.org/10.1039/B207281P; (b) M. Cossi, V. Barone, Time-Dependent 
Density Functional Theory For Molecules In Liquid Solutions. J. Chem. Phys., 2001, 115, 4708-4717 https://doi.org/10.1063/1.1394921.

[22] M. J. Frisch, G. W. Trucks, H. B. Schlegel, G. E. Scuseria, M. A. Robb, J. R.

Cheeseman, G. Scalmani, V. Barone, B. Mennucci, G. A. Petersson, H. Nakatsuji, M. Caricato, X. Li, H. P. Hratchian, A. F. Izmaylov, J. Bloino, G. Zheng, J. L. Sonnenberg, M. Hada, M. Ehara, K. Toyota, R. Fukuda, J. Hasegawa, M. Ishida, T. Nakajima, Y. Honda, O. Kitao, H. Nakai, T. Vreven, J. A. Montgomery Jr, J. E. Peralta, F. Ogliaro, M. Bearpark, J. J. Heyd, E. Brothers, K. N. Kudin, V. N. Staroverov, R. Kobayashi, J. Normand, K. Raghavachari, A. Rendell, J. C. Burant, S. S. Iyengar, J. Tomasi, M. Cossi, N. Rega, J. M. Millam, M. Klene, J. E. Knox, J. B. Cross, V. Bakken, C. Adamo, J. Jaramillo, R. Gomperts, R. E. Stratmann, O. Yazyev, A. J. Austin, R. Cammi, C. Pomelli, J. W. Ochterski, R. L. Martin, K. Morokuma, V. G. Zakrzewski, G. A. Voth, P. Salvador, J. J. Dannenberg, S. Dapprich, A. D. Daniels, E. O. Farkas, J. B. Foresman, J. V. Ortiz, J. Cioslowski and D. J. Fox, Gaussian 09, Revision C.01, Gaussian, Wallingford, CT, 2009.

[23] V. D. Gupta, A. B. Tathe, V. S. Padalkar, P. G. Umape, N. Sekar, Red emitting solid state fluorescent triphenylamine dyes: Synthesis, photo-physical property and DFT study, Dyes Pigm. 97 (2013) 429-439. https://doi.org/10.1016/j.dyepig.2012.12.024.

[24] a) R. Lartia, C. Allain, G. Bordeau, F. Schmidt, C. Fiorini-Debuischert, F. Charra, M. P. Teulade-Fichou, Synthetic Strategies to Derivatizable Triphenylamines Displaying High TwoPhoton Absorption, J. Org. Chem. 73 (2008) 1732-1744. https://doi.org/10.1021/jo702002y; b) M. Fecková, P. le Poul, F. Robin-le Guen, T. Roisnel, O. Pytela, M. Klikar, F. Bureš, S. Achelle, 2,4-Distyryl- and 2,4,6-Tristyrylpyrimidines: Synthesis and Photophysical Properties, J. Org. Chem. 83, (2018) 11712-11726. https://doi.org/10.1021/acs.joc.8b01653

[25] C. Reichardt, Solvatochromic Dyes as Solvent Polarity Indicators, Chem. Rev. 94 (1994) 2319-2358. https://doi.org/10.1021/cr00032a005. 
[26] a) K. D. Singer, A. F. Garito, Measurements of molecular second order optical susceptibilities using dc induced second harmonic generation, J. Chem. Phys. 75 (1981) 3572. https://doi.org/10.1063/1.442467 ; b) B. F. Levine, C. G. Bethea, Molecular hyperpolarizabilities determined from conjugated and nonconjugated organic liquids, Appl. Phys. Lett., 24 (1974) 445. https://doi.org/10.1063/1.1655254 ; c) I. Ledoux, J. Zyss, Influence of the molecular environment in solution measurements of the Second-order optical susceptibility for urea and derivatives, J. Chem. Phys. 73, (1982) 203-213. https://doi.org/10.1016/0301-0104(82)85161-6.

[27] a) J. L. Oudar, D. S. Chemla, Hyperpolarizabilities of the nitroanilines and their relations to the excited state dipole moment, J. Chem. Phys. 66 (1977) 2664-2668. https://doi.org/10.1063/1.434213, (b) D. R. Kanis, M. A. Ratner, T. Marks, Design and construction of molecular assemblies with large second-order optical nonlinearities. Quantum chemical aspects, J. Chem. Rev. 94 (1994) 195-242. https://doi.org/10.1021/cr00025a007 [28] C. Rothe, D. Neusser, N. Hoppe, K. Dirnberger, W. Vogel, S. Gámez-Valenzuela, J. T. López-Navarrete, B. Villacampa, M. Berroth, M. C. Ruiez-Delgado, S. Ludwigs, Push-pull thiophene chromophores for electro-optic applications: from 1D linear to $\beta$-branched structures., Phys. Chem. Chem. Phys. $22 \quad$ (2020) 2283-2294. https://doi.org/10.1039/C9CP05640H 


\section{CAPTIONS}

\section{Scheme Captions}

Scheme 1. Synthesis of 1,1-dicyano-2,4-diaryl-1,3-butadiene derivatives (3a-d). (i) malononitrile, $\mathrm{NH}_{4} \mathrm{OAc} / \mathrm{AcOH}$, MWI (ii) Q-CHO, ethanol, piperidine.

\section{Figure Captions}

Fig. 1. Normalized absorption (solid lines) and emission (dashed lines) spectra of compounds 3a-d in chloroform solution

Fig. 2. Normalized emission spectra of $\mathbf{3 a}$ in different aprotic solvents

Fig. 3. Normalized solid state (powder) spectra of compounds 3a-d.

Fig. 4. Emission of compound $\mathbf{3 a}$ and $\mathbf{3 c}$ in solid state (powder). Photograph was taken in the dark upon irradiation with a hand-held UV $\operatorname{lamp}\left(\lambda_{\mathrm{em}}=366 \mathrm{~nm}\right)$

Fig. 5. The optimized geometries of compounds 3a-d in ground and excited state at B3LYP/6311g(d) in $\mathrm{CHCl}_{3}$.

Fig. 6. The molecular orbitals of compounds 3a-d in ground and excited state.

Fig. 7. TGA curves of chromophores 3a-d under nitrogen gas in the temperature range of 25$600{ }^{\circ} \mathrm{C}$ at a heating rate of $10{ }^{\circ} \mathrm{C} \mathrm{min}^{-1}$.

\section{Table Captions}

Table 1. UV-Vis and photoluminescence (PL) data of compounds 3a-d in $\mathrm{CHCl}_{3}$ solution

Table 2. Emission solvatochromism of compounds 3a-d in various aprotic solvents.

Table 3. The absorption and emission spectra data obtained from TD-DFT calculations in $\mathrm{CHCl}_{3}$ for compounds 3a-d.

Table 4. Results for EFISH measurements for compounds 3a-d. 


\section{CREDIT AUTHOR STATEMENT}

Mohamed Yahya: Investigation, Writing - Review \& Editing. Nurgül Seferoğlu: Conceptualization, Software, Writing - Review \& Editing. Alberto Barsella: Conceptualization, Methodology. Sylvain Achelle: Conceptualization, Methodology, Writing

- original draft - Review \& Editing. Zeynel Seferoğlu: Supervision, Writing - Review \& Editing

Declaration of interests

$\bigotimes$ The authors declare that they have no known competing financial interests or personal relationships that could have appeared to influence the work reported in this paper.

$\square$ The authors declare the following financial interests/personal relationships which may be considered as potential competing interests:

\section{Graphical abstract}


High NLO response
$\mu \beta_{\text {EFISH }}=870.10^{-48}$ esu

Rapid Synthesis by MWI
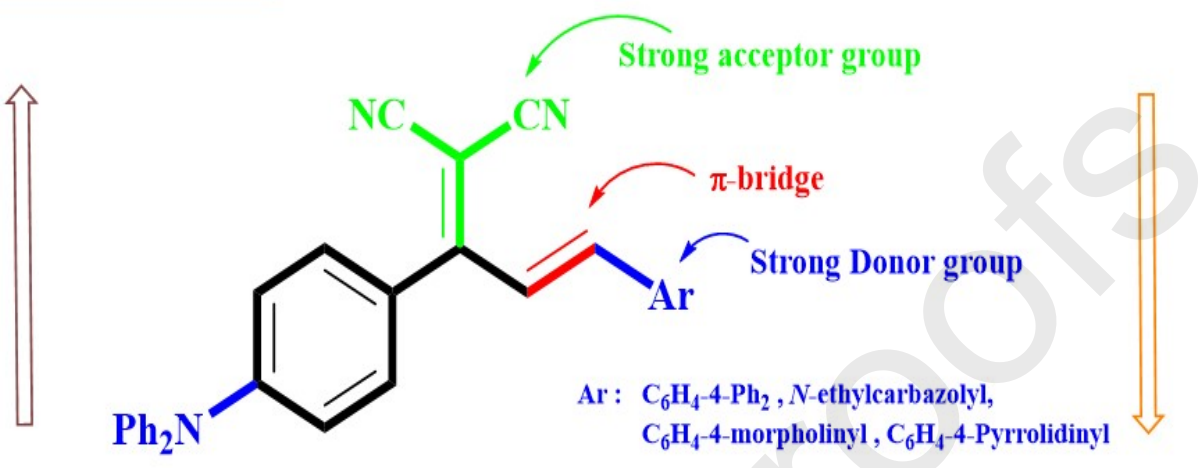

High Thermal Stability
Strong red-near infrared emission in solid state
Orange red emission in solution

\section{Highlights}


- A series of allylidenemalononitrile push-pull chromophores were designed and synthesized.

- These compounds display orange-red emission both in chloroform solution and in solid-state.

- $\mu \beta_{0}$ second-order NLO response up to $870 \times 10^{-48}$ esu were obtained.

- These series of chromophores exhibit high thermal stability 